\title{
Strokovna samozavest pri spodbujanju bralne pismenosti
}

\author{
Professional self-confidence in reading literacy promotion
}

\section{Sabina Fras Popović ${ }^{1}$}

IZVLEČEK: V prispevku ugotavljamo pozitiven vpliv udeležbe na strokovnih dogodkih s področja bralne pismenosti in bralne kulture na krepitev strokovne samozavesti strokovnih delavcev $v$ knjižnicah. Javni podatki kažejo dostopnost strokovnih dogodkov na področju spodbujanja bralne pismenosti in bralne kulture $v$ Sloveniji. Praktiki se udeležujejo tovrstnih izobraževanj, a hkrati dvomijo $v$ svojo usposobljenost za delo na področju spodbujanja in načrtovanja bralne pismenosti in bralne kulture. $V$ prispevku smo uporabili raziskovalno metodologijo 1) pregleda javno dostopnih podatkov in objavljenih raziskav in 2) študijo primera, ki je vključila tudi metodo anketiranja. Raziskava konkretnega dogodka in širše predvidevanje sta pokazala, da strokovni dogodki pomembno vplivajo na strokovno samozavest, na razumevanje osebne vloge posameznika in njegov prispevek pri spodbujanju bralne pismenosti ter tako oblikujejo odnos posameznika do branja in knjige. Študija primera je vezana na dogodek $A B C$ bralne pismenosti, ki ga pripravlja Center za spodbujanje bralne pismenosti Mariborske knjižnice. Na osrednje vprašanje o ugotavljanju vpliva smo vezali še vprašanje o občutkih udeležencev ob prenosu strokovnega dogodka iz fizičnega v spletno okolje. Pri občutkih udeležencev ob spremljanju dogodkov na spletu je zadovoljstvo ob druženju s kolegi in s prireditvenim prostorom v večji meri zamenjalo zadovoljstvo s podanimi vsebinami.

KLJUČNE BESEDE: bralna pismenost, bralna kultura, vpliv, strokovna samozavest, strokovni dogodki

ABSTRACT: Participation in professional events in the fields of reading literacy and reading culture has a positive impact on boosting professional self-confidence. The available data reflects the accessibility of professional events for the promotion of reading literacy and reading culture in Slovenia. Practitioners attend such training, but at the same time, they doubt their competence to encourage and plan the development of reading literacy and reading culture. This study uses research methodology of 1) a review of publicly available data and published research, and 2) case study, with survey method. The question about the participants' feelings when transferring a professional event from a physical to an online environment has been added to the main research question. The research shows that professional events have a significant impact on professional self-confidence, on understanding one's role and her/his contribution to the reading literacy promotion, and thus, they shape one's attitude towards reading and books. In terms of participants' feelings when watching events online, satisfaction with socialising with colleagues and with the event venue is replaced by satisfaction with the content provided. The case study is based on an event organised by the Centre for Reading Literacy Promotion at the Maribor Public Library.

KEYWORDS: reading literacy, reading culture, impact, professional self-confidence, professional events

\section{Uvod ali „Če hočeš druge vneti, moraš sam goreti«}

Neposredno blizu Mariborske knjižnice stojita spomenik, posvečen Antonu Martinu Slomšku, in trg, poimenovan po njem. Anton Martin Slomšek je prepoznan tudi kot skrbnik slovenskega

\footnotetext{
${ }^{1}$ Dr. Sabina Fras Popović, višja bibliotekarska svetnica, Mariborska knjižnica, Center za spodbujanje bralne pismenosti, Maribor, Slovenija, sabina.fras-popovic@mb.sik.si.
} 
jezika in šolski reformator. Njegova misel „Če hočeš druge vneti, moraš sam goreti« je poetičen zapis našega raziskovalnega vprašanja. Zakonitosti znanstvenega publiciranja imajo priprta vrata za kreativnost $v$ izražanju, zato $v$ nadaljevanju Slomškovo misel vežemo na klasična poglavja znanstvenega publiciranja: uvod, pregled literature, raziskovalni problem in metodologijo ter rezultate in razpravo. Ob teh poimenovanjih posameznih poglavij uvajamo izpeljanke te Slomškove misli.

V središču našega razmišljanja o ugotavljanju vpliva usposabljanj na strokovno samozavest je postavljen strokovni dogodek $A B C$ bralne pismenosti $(2019,2020)$, ki ga pripravlja Center za spodbujanje bralne pismenosti Mariborske knjižnice (2021). Mariborska knjižnica je kot ena od desetih osrednjih območnih knjižnic prevzela naloge na področju spodbujanja bralne pismenosti in s 1. 1. 2019 ustanovila Center za spodbujanje bralne pismenosti. Ustanovitev tega centra je logično nadaljevanje več desetletij dolge tradicije Mariborske knjižnice na področju dela z mladimi bralci ${ }^{2}$. Ključni sta revija Otrok in knjiga in Služba za mlade bralce, ki sta na nacionalnem nivoju prepoznani kot preplet sistematičnega in celostnega obravnavanja vprašanj, povezanih z mladimi bralci. Center za spodbujanje bralne pismenosti, ki je namenjen knjižničarjem vseh slovenskih splošnih knjižnic, spodbuja sodelovanje med knjižničarji različnih knjižnic ter povezovanje knjižničarjev in drugih deležnikov na področju bralne pismenosti v Sloveniji.

Vlada Republike Slovenije je 19. decembra 2019 sprejela Nacionalno strategijo za razvoj bralne pismenosti za obdobje 2019-2030. Tako smo v Sloveniji dobili »strateški dokument, ki določa prednostne naloge in vzgojno-izobraževalne cilje na področju pismenosti« (Nacionalna, 2019, str. 4). Vizija strategije je, da bi dosegli raven bralne pismenosti, ki bi vsakomur omogočala optimalen razvoj sposobnosti za dejavno življenje in delo (Nacionalna, 2019, str. 5).

Pojma bralna pismenost in bralna kultura sta $v$ javnem družbenem življenju in $v$ prostoru strokovnega delovanja pogosto uporabljena. Mi bomo pojma razumeli tako, kot ju opredeljuje Nacionalna strategija za razvoj bralne pismenosti:

„Bralna pismenost je stalno razvijajoča se zmožnost posameznika in posameznice za razumevanje, kritično vrednotenje in uporabo pisnih informacij. Ta zmožnost vključuje razvite bralne veščine, (kritično) razumevanje prebranega in bralno kulturo (pojmovanje branja kot vrednote in motiviranost za branje). "(Nacionalna, 2019, str. 3)

„Pomemben del pismenosti je bralna kultura, opredeljena kot odnos (splet pojmovanj in vrednot) posameznika in posameznice ter družbe do knjige in branja. " (Nacionalna, 2019, str. 4)

$\checkmark$ prispevku nas zanima strokovna samozavest knjižničarjev in knjižničark, ki imajo v različnih okoljih družbe moč, privilegij ali dolžnost ustvarjati odnos in (na)učiti veščine.

Posebej nas zanima, ali strokovni dogodki, ki so vir permanentnega izpopolnjevanja, usposabljanja in izobraževanja, pozitivno vplivajo na strokovno samozavest knjižničarjev in knjižničark, torej strokovnih delavcev v knjižnicah. Preverjamo tudi tezo, da pri (ne)spodbujanju bralne pismenosti in bralne kulture pri različnih ciljnih skupinah prebivalcev

\footnotetext{
${ }^{2}$ Mariborska knjižnica ima že več kot pet desetletji vzpostavljeno notranjo organizacijsko enoto (Služba za mlade bralce), ki celostno pokriva področje dela z mladim bralcem (npr. načrtovanje bibliopedagoških aktivnosti, nabava in obdelava knjižničnega gradiva za mlade, oblikovanje vsebin v pionirskih in mladinskih oddelkih).
} 
in prebivalk Slovenije lahko ključno vlogo odigrajo tisti odrasli, ki niso zainteresirani in navdušeni za spodbujanje bralne pismenosti in gradnjo bralne kulture. Na osrednje vprašanje smo vezali še vprašanje o občutkih udeležencev ob prenosu strokovnega dogodka iz fizičnega v spletno okolje.

V prispevku smo uporabili raziskovalno metodologijo 1) pregleda javno dostopnih podatkov in objavljenih raziskav in 2) študijo primera, ki je vključila tudi metodo anketiranja.

Našo raziskavo ugotavljanja vpliva strokovnih dogodkov na strokovno samozavest strokovnih delavcev v knjižnicah vežemo na le en dogodek, in to je dogodek $A B C$ bralne pismenosti, ki ga pripravlja Center za spodbujanje bralne pismenosti Mariborske knjižnice. Čeprav je $v$ slovenskem prostoru ponudba strokovnih dogodkov na področju bralne kulture in bralne pismenosti tolikšna, da bi lahko pozitivno vplivala ${ }^{3}$ na strokovno samozavest osebja, je $v$ program omenjenega centra umeščen redni letni strokovni dogodek kot osrednja metoda dela. Predpostavljamo, da ta metoda dela omogoča doseganje strateških ciljev nacionalne strategije in udejanjanje posameznih elementov modela proaktivne splošne knjižnice za spodbujanje bralne kulture in bralne pismenosti, ki ga je v slovenskem knjižničnem prostoru postavila Vilar (2017). Glavni namen tega strokovnega dogodka je ustvarjanje pozitivnega družbenega okolja za spodbujanje bralne pismenosti in krepitev strokovnih kompetenc splošnih knjižničarjev.

\section{Pregled literature ali kako vneti, če sam ne upam, ne znam ali ne zmorem goreti}

Nacionalna strategija za razvoj bralne pismenosti (2019) (dalje: nacionalna strategija) v središče postavlja uresničevanje ciljev skozi vzgojno-izobraževalni proces in je v veliki meri usmerjena na aktivnosti znotraj vzgojno-izobraževalnih institucij. Poudarja sodelovanje različnih akterjev ter povezovanje $v$ mrežo izvajalcev za razvijanje in usklajevanje programov bralne pismenosti in bralne kulture. $V$ tem lahko prepoznamo pomembno vlogo splošnih knjižnic ter partnerstva med splošno knjižnico in vzgojno-izobraževalno institucijo pri doseganju strateških ciljev nacionalne strategije.

Javnost, sodeč po raziskavi Združenja splošnih knjižnic iz leta 2011, meni, da splošne knjižnice pomembno prispevajo k razvijanju bralne kulture in dvigovanju izobrazbene ravni v skupnosti. Rezultati so pokazali izjemno visoko stopnjo strinjanja s posameznimi trditvami o tej temi. V povprečju je trditev, ki se je nanašala na razvoj branja, bralne kulture in pismenosti, imela najvišjo oceno. Pri tem med člani, uporabniki in neuporabniki ni bilo statistično značilnih razlik, kar pomeni, da gre za enotno percepcijo širše družbene koristnosti splošnih knjižnic (Javnomnenjska, 2011, str. 43). Ambrožičeva je leta 2016 predstavila rezultate javnomnenjske raziskave o odnosu javnosti do knjižnične javne službe, ki je tudi obravnavala vprašanje koristi oziroma vpliva na posameznika in skupnost. Tudi tukaj ugotovitve kažejo, da so knjižnice nujne za razvoj posameznika in okolja ter bistvene za dvig pismenosti in bralne kulture (Ambrožič, 2016). V letu 2020 je bila ponovno izpeljana raziskava med člani, uporabniki in neuporabniki slovenskih splošnih knjižnic (Raziskava, 2020), a v tej raziskavi ni bilo podobnih, primerljivih vprašanj kot leta 2011.

\footnotetext{
${ }^{3} \mathrm{O}$ tem vplivu ne moremo trditi zagotovo; večina organizatorjev po dogodku sicer izvaja evalvacije med udeleženci, a te $v$ večini temeljijo na ugotavljanju zadovoljstva, in ne vpliva. Vsekakor pa ta vpliv predpostavljamo.
} 
Spodbujanje bralne pismenosti in vzpostavljanje bralne kulture splošne knjižnice dosegajo z razvejano mrežo knjižnic in s programskimi usmeritvami, t. i. knjižničnimi vlogami, ki so opredeljene v dokumentu Strokovna priporočila in standardi za splošne knjižnice (2019) (dalje: strokovna priporočila).

Knjižnična vloga je »ciljno usmerjeno področje dejavnosti knjižnice, ki opisuje, kaj knjižnica dela ali zagotavlja z namenom zadovoljevanja opredeljene potrebe lokalne skupnosti« (Strokovna, 2019, str. 17). V strokovnih priporočilih za splošne knjižnice so štiri od enajstih knjižničnih vlog neposredno povezane $z$ bralno pismenostjo in bralno kulturo ter usmerjene na različne uporabniške skupine. Te vloge so:

- razvoj predbralne pismenosti,

- bralna kultura in bralna pismenost otrok,

- bralna kultura in bralna pismenost mladostnikov,

- bralna kultura in bralna pismenost odraslih.

Posredno povezane z bralno pismenostjo in bralno kulturo so še štiri knjižnične vloge: pridobivanje znanja, informacijsko in računalniško opismenjevanje, informacijsko središče lokalne skupnosti in vključevanje $v$ družbo. Preostale tri knjižnične vloge iz strokovnih priporočil so vsebinsko sicer vezane na druga področja, a jih je nemogoče uresničevati v okolju, kjer pismenost ni na zadovoljivi ravni in prevladuje negativen odnos do branja in knjige ali odnosa sploh ni.

V presečišču omenjenih nacionalnih dokumentov so strokovni delavci in delavke različnih profilov ključni za oblikovanje in uresničevanje programov za spodbujanje bralne pismenosti in bralne kulture. Nacionalna strategija določa, da je vsem, ki so zavezani »razvoju lastne bralne pismenosti in bralne kulture ter razvoju bralne pismenosti in bralne kulture učečih se«, treba "zagotoviti potrebna znanja na dodiplomski in podiplomski stopnji izobraževanja ter v okviru stalnega strokovnega usposabljanja. Njihovo motivacijo in strokovno avtonomijo omogočimo z zagotavljanjem možnosti za stalno strokovno rast« (Nacionalna, str. 8). V strokovnih priporočilih pa je pri knjižničnih vlogah poudarek na »kompetencah kot potrebnih veščinah, sposobnostih in znanju, ki je potrebno za izvedbo aktivnosti specifične vloge» (Strokovna, 2019, str. 58).

Stalni strokovni razvoj in kompetence strokovnih delavcev so vezani na sodelovanje $v$ procesu vseživljenjskega izobraževanja. Na področju odnosa do branja in knjige so se $v$ zadnjem desetletju zaradi ugotovitev nevroznanosti zgodili vsebinski premiki. Ti so vezani na predstavljanje branja kot ene od pomembnejših aktivnosti, ki vplivajo na razvoj in delovanje možganov. Pri tem je izpostavljena jasna ločnica med branjem tiskanih besedil in branjem na zaslonu (prim. Wolf, 2021; Lustig, 2020; Alter, 2019; Furedi, 2017; Saltz, 2019; Spitzer, 2016, 2021). Spremljanje novih in utrjevanje že znanih vsebin peljeta po našem mnenju do gradnje strokovne samozavesti strokovnih delavcev.

Vilar je v znanstveni monografiji Proaktivna splošna knjižnica za bralno pismenost in bralno kulturo (2017) postavila teoretičen model proaktivne splošne knjižnice za spodbujanje bralne pismenosti in bralne kulture. Model sestavljajo: odnos osebja do bralne pismenosti, organizacijski dejavniki, aktivno delovanje in vrednotenje delovanja. Po mnenju avtorice »model skuša sistematizirati različne dejavnike, ki pogojujejo oziroma uveljavljajo aktivno vlogo splošne knjižnice pri razvoju bralne pismenosti in bralne kulture. (Vilar, 2017, str. 101). 
Nastal je na izhodiščih raziskave, v kateri so sodelovali knjižničarji (fokusna skupina) in splošne knjižnice (anketa). Pri interpretaciji rezultatov raziskave avtorica opozarja na problem premajhnega vzorca, saj je $v$ raziskavi sodelovalo le od 30 od 58 splošnih knjižnic, a so rezultati raziskave $v$ povezavi $z$ odgovori fokusne skupine dovolj zgovorni. Trenutno so rezultati te raziskave edini rezultati $v$ slovenskem prostoru, ki kažejo odnos splošnih knjižnic do posameznih področij modela proaktivne splošne knjižnice za spodbujanje bralne pismenosti in bralne kulture ter osebna in strokovna stališča knjižničarjev, ki delujejo na tem področju. (Vilar, 2017, str. 101)

Sodeč po ugotovitvah omenjene raziskave lahko razumemo, da ima strokovno osebje dvojno podobo v odnosu do bralne kulture in bralne pismenosti. Strokovno osebje bralno kulturo in bralno pismenost lahko spodbuja (prva podoba) ali zavira (druga podoba). Knjižničarji so $v$ raziskavi "poudarili, da je najpomembnejši dejavnik osebje« (Vilar, 2017, str. 52). S tem so se strinjali tudi predstavniki iz splošnih knjižnic in izpostavili, da je usposobljeno strokovno osebje ključen in odločilen dejavnik, "ki pa prevečkrat temelji na lastni osebni zavzetosti." (Vilar, 2017, str. 102) Hkrati pa izpostavljajo, da je strokovna usposobljenost osebja problematičen dejavnik, saj niso povsem oziroma ne $v$ vseh primerih zadovoljni z usposobljenostjo osebja. Poleg tega »ocenjujejo, da na tem področju nimajo veliko možnosti za izboljšanje stanja, saj mnoge [splošne knjižnice] menijo, da imamo v slovenskem prostoru le delno ustrezno ponudbo usposabljanj, ki bi omogočila izpopolnjevanje strokovnih delavcev." (Vilar, 2017, str. 102)

V raziskavi ni podatka, kakšna bi bila ustreznejša ponudba usposabljanj, ki bi omogočila izpopolnjevanje strokovnih delavcev. Ugotovitev, da vodstvo splošnih knjižnic ocenjuje, da je strokovno osebje $v$ splošnih knjižnicah premalo usposobljeno za razvoj bralne kulture in spodbujanje bralne pismenosti ter da strokovni delavci $v$ splošnih knjižnicah sami niso popolnoma prepričani v svojo dobro usposobljenost za delo na področju bralne kulture, pa je izhodišče programskih smernic Centra za spodbujanje bralne pismenosti Mariborske knjižnice. Te programske smernice se navezujejo na potrebo strokovnega osebja v splošnih knjižnicah po permanentnem usposabljanju in izpopolnjevanju s področja bralne kulture in bralne pismenosti. Za izvedbo tega usposabljanja in izpopolnjevanja so predvidene različne oblike in načini. Potreba po permanentnem strokovnem usposabljanju in izpopolnjevanju je $v$ programskih smernicah Centra za spodbujanje bralne pismenosti nadgrajena $s$ temeljnimi načeli nacionalne strategije za razvoj bralne pismenosti.

"Temeljna načela nacionalne strategije opredeljujejo splošne usmeritve na vseh ravneh, področjih in dejavnostih, ki vplivajo na razvoj bralne pismenosti in oblikujejo učna okolja za razvoj pismenosti." (Nacionalna, 2019, str. 6). Temeljna načela so: bralna pismenost kot vseživljenjska pravica, odgovornost in vrednota (1), ozaveščenost o pomenu bralne pismenosti in njena promocija (2), celostni pristop (3), dostopnost, enakopravnost in pravičnost (4), individualizacija in personalizacija (5), strokovna odličnost in odgovornost (6), velika pričakovanja in standardi (7), raznovrstnost branja (8), načrtovanje, vrednotenje in samovrednotenje (9).

Kompetence so "znanja, veščine, spretnosti, lastnosti, sposobnosti, zmožnosti, ravnanja in vedenja v delovnem procesu, ki omogočajo posamezniku, da ustrezno opravlja svoje delovne naloge. Povezane so z zahtevami dela in poslovnimi potrebami $v$ določenem delovnem okolju.« (Strokovna, 2019, str. 18). Kompetence pa lahko razumemo tudi kot "zmožnost 
posameznika, da aktivira, uporabi in poveže pridobljeno znanje v kompleksnih, raznovrstnih in nepredvidljivih situacijah. " (Fras Popović, 2016, str. 41) Kompetence delimo v splošne in specifične. Splošne kompetence so tiste, ki v največji meri zaznamujejo posameznikovo osebno življenje. V literaturi lahko najdemo zanje različne izraze: ključne kompetence, generične kompetence, prenosljive kompetence in še kaj podobnega. Mi bomo uporabili termin osebne kompetence, saj so le-te $v$ največji meri vezane na značaj posameznika in njegovo zasebno življenje, in so tudi prenosljive med poklici, saj jih posameznik tako rekoč prinese s seboj. Specifične kompetence $v$ našem primeru imenujemo strokovne kompetence, vezane so na posamezno področje dela. Še tako dobro razvite osebne kompetence ne morejo nadomestiti specifičnih, poklicnih kompetenc, zato so za posamezna delovna področja le-te določene (npr. s predpisano izobrazbo).

Strokovna priporočila poudarjajo, da »kakovost knjižnične storitve temelji na kakovosti dela in odgovornosti knjižničnega delavca $v$ odnosu do njegovega delovnega področja znotraj knjižnice." (Strokovna, str. 38) Ob tem so opredeljene tudi zahteve po določeni stopnji izobrazbe ter vseživljenjskem strokovnem izpopolnjevanju in usposabljanju. Te specifične kompetence so nadgrajene $z$ dodatnim opisom, vezanim na izvajanje posamezne knjižnične vloge (npr. pri razvoju predbralne pismenosti mora imeti osebje še posebne kompetence, kot npr. poznavanje otrokovega razvoja ter poznavanje otroške literature in načinov predbralne pismenosti) (Strokovna, 2019, str. 63).

Knjižničarji poudarjajo, da «ni pomembno le ozko strokovno bibliotekarsko znanje ter upoštevanje pravil in določil, temveč tudi občutek za delo z uporabniki. Prav za spodbujanje bralne pismenosti in bralne kulture je izredno pomembna usposobljenost knjižničarjev, motivacija, znanje in samoiniciativnost.« (Vilar, 2017, str. 52) Za spodbujanje bralne pismenosti in bralne kulture v prostoru delovanja splošnih knjižnic in tudi v širšem prostoru so pomembni specifično znanje, ki je opisano $v$ strokovnih kompetencah, in tudi splošne kompetence, $\mathrm{ki}$ jih nekdo prinese in odnese s seboj. Vilar (2017, str. 51) navaja, da so »knjižničarji opozorili, da bi bilo treba izboljšati sodelovanje in sodelovalnost knjižnic in preseči občutek ogroženosti glede delitve idej in dobrih praks oziroma na tem področju vzpostaviti bolj pozitivno sodelovalno klimo" in se »na nacionalni ravni dogovoriti za skupne cilje in jih poskušali doseči, četudi vsak na svoj način (npr. izboljšanje družinske pismenosti). « Nujnost sodelovanja in nacionalno dogovorjene cilje prinaša nacionalna strategija. Kljub temu da nas določila te strategije v večji meri usmerjajo v vzgojno-izobraževalni prostor (npr. poglavje šest z naslovom Cilji in ravni pismenosti po posameznih stopnjah izobraževanja), je prav povezovanje različnih akterjev eno od glavnih vodil te nacionalne strategije. "Za razvoj bralne pismenosti so odgovorni vlada, ministrstva, mediji, lokalna skupnost, strokovni delavci in delavke ${ }^{4}$ ter drugi izobraževalci in izobraževalke, delodajalci in delodajalke, starši ter vsak posameznik in posameznica zase." (Nacionalna, str. 6) Nadalje je povezanost akterjev tudi eden od pogojev za izboljšanje bralne pismenosti in razvoj bralne kulture, saj je izpostavljena temeljna značilnost knjižničnega sistema, to je vertikalna in horizontalna povezanost različnih

\footnotetext{
4 „V strategiji izraz strokovni delavci pomeni strokovne delavce in delavke v vzgoji in izobraževanju (vzgojitelji/-ce, učitelji/ce, profesorji/-ice, šolski/-e knjižničarji/-ke, svetovalni/-e delavci/-ke ipd.), kulturi in drugih ustanovah javnega pomena." (Nacionalna, str. 6). Če bi na tem mestu razdelali tudi področje kulture, bi bili tukaj posebej izpostavljeni tudi splošni/-e knjižničarji/-ke, ustvarjalci/-ke, pisatelji/-ce ipd., pri drugih ustanovah javnega pomena bi (upajmo) našli izpostavljene pediatre in pediatrinje, psihologe in psihologinje, trenerje in trenerke v športnem društvu/klubu, voznike in voznice avtobusa ali vlaka.
} 
vrst knjižnic z namenom, da je knjižnična javna služba dostopna vsem prebivalkam in prebivalcem $v$ različnih življenjskih obdobjih. $\vee$ nacionalni strategiji je določeno, da je treba ustvariti partnerstvo med šolskimi, visokošolskimi in splošnimi knjižnicami za skupno načrtovanje programov, temelječih na strokovnih izhodiščih za doseganje ciljev in ravni bralne pismenosti. Ob povezanosti knjižnic je pomembna tudi mreža izvajalcev, ki uresničujejo nacionalno strategijo. Treba je oblikovati državno medresorsko mrežo izvajalcev, zagotoviti sodelovanje različnih ustanov na različnih ravneh (lokalna, regionalna), na ravni vrtca/šole in vseh deležnikov (Nacionalna, str. 14).

\section{$3 \mathrm{Na}$ poti raziskovanja, kako in zakaj goreti: raziskovalni problem in metodologija}

$\mathrm{Na}$ področju bralne pismenosti in bralne kulture so vsebine za potrebe izobraževanja, usposabljanja in izpopolnjevanja dostopne $v$ programih formalnega izobraževanja ${ }^{5}$ na dodiplomski in podiplomski stopnji ter v programih neformalnega izobraževanja ${ }^{6}$. Raznolikost je prisotna pri obeh vrstah ponudbe. $V$ našem primeru se bomo osredotočili na izbran dogodek, ki ga uvrščamo v sklop neformalnega izobraževanja.

\subsection{Raziskovalni problem ali res ne zmorem/upam/znam goreti ali smisel strokovne samozavesti}

Spremljanje ponudbe neformalnega izobraževanja v obdobju od 2018 do 2020 na osnovi javno dostopnih podatkov (npr. spletne strani, vabila na družabnih omrežjih, oglasi, npr. v reviji Bukla, vabila prek nacionalne mreže za kulturno-umetnostno vzgojo (mreže KUV)) je izrisalo pokrajino strokovnih dogodkov različnih zahtevnostnih stopenj in vsebinskih usmeritev. Vsebinska analiza ponudbe in profila ponudnikov bi bila vsekakor zanimiva, a to ni namen tega prispevka. Zanima nas, kakšen odnos imajo strokovni delavci in delavke $v$ splošnih knjižnicah do strokovne usposobljenosti za delo na področju bralne kulture in bralne pismenosti.

Pri anketirancih nismo ugotavljali njihovega pogleda na lastno strokovno samozavest in na oceno lastnih osebnih ter specifičnih kompetenc. Da imajo udeleženci po strokovnem dogodku, ki se ga udeležijo, večjo strokovno samozavest kot prej oziroma je na njihovo strokovno samozavest vplivala udeležba na strokovnem dogodku, ugotovimo iz njihovih odgovorov $v$ anketi. Ti odgovori vsebujejo tudi samooceno vpliva dogodka na njihovo samozavest. Zanima nas vpliv udeležbe na točno določenem strokovnem dogodku na njihove osebne in strokovne kompetence ter strokovno samozavest.

Opredelitev termina vpliv povzemamo po mednarodnem standardu SIST ISO 16439:2015 Informatika in dokumentacija - Metode in postopki za ocenjevanje vpliva knjižnic (2015, str. 10), kjer je vpliv definiran kot "sprememba ali razlika v vedenju posameznika ali družbe, ki je posledica stika s storitvami knjižnice. Sprememba je lahko opredmetena ali neopredmetena." Iz standarda tudi prevzemamo opredelitev termina dogodek, ki je "predhodno dogovorjena aktivnost s kulturnim, izobraževalnim, socialnim, političnim, poučevalnim ali kakim drugim namenom. Vključeni so samo dogodki, ki jih organizira knjižnica sama ali v sodelovanju z

\footnotetext{
${ }^{5}$ Npr. na Pedagoški fakulteti Univerze v Mariboru (predmet Družinska pismenost) in na Pedagoški fakultete Univerze na Primorskem (predmet Zgodnja pismenost in otroška književnost).

${ }^{6}$ Npr.: DBZ - ZPM, MKL, Pionirska - Center za mladinsko književnost in knjižničarstvo. Zavod RS za šolstvo, ZBDS, Kulturni bazar, portal Dobre knjige, revija Otrok in knjiga.
} 
drugimi institucijami, znotraj ali zunaj prostorov. Dogodki, ki se odvijajo v knjižnici, vendar jih organizirajo zunanje institucije brez sodelovanja knjižnice, so izključeni« (ISO, 2015, str. 9).

\subsection{Metodologija ali kako ugotoviti moč plamena}

Po pregledu strokovne literature smo se za ugotavljanje vpliva udeležbe na strokovnih dogodkih s področja bralne pismenosti in bralne kulture odločili, da bomo s študijo primera preučili vpliv dogodka $A B C$ bralne pismenosti, $v$ katero smo vključili metodo ankete na namenskem vzorcu.

Strokovni dogodek z naslovom $A B C$ bralne pismenosti je bil do zdaj izpeljan dvakrat, in sicer dve leti zapored: leta 2019 ABC bralne pismenosti in leta 2020 ABC bralne pismenosti II, a v dveh različnih formah. Prvič je bil izpeljan 28. maja 2019, ko je potekal med 9.30 in $17.30 \mathrm{~s}$ tremi odmori, drugič pa med 5. in 9. oktobrom 2020, ko so bila na programu enourna predavanja. Zvrstilo se je sedem predavanj. Dogodek se ni odvijal 6. oktobra 2020 zaradi organizacije Kulturnega bazarja $v$ Ljubljani in $\mathrm{s}$ tem morebitnega podvajanja vsebin pri zainteresirani javnosti.

Anketiranje smo izvedli po posameznem dogodku, udeležencem smo povezavo do ankete posredovali po elektronski pošti. Udeleženci strokovnega dogodka so s spletno anketo podali povratno informacijo o vplivu, ki ga je nanje imela udeležba na določenem dogodku. Spletna anketa, ki je bila pripravljena z orodjem 1AK, je bila zasnovana tako, da je omogočala primerjavo obeh dogodkov. Pri prvem dogodku v letu 2019 je anketa obsegala šest vprašanj zaprtega tipa in eno vprašanje odprtega tipa. Za dogodek v letu 2020 pa smo v anketo vključili devet vprašanj zaprtega tipa in ponovno eno vprašanje odprtega tipa. Vprašanja zaprtega tipa so imela podvprašanja. O namenu ankete so bili anketiranci obveščeni v kratkem nagovoru pred začetkom izpolnjevanja ankete.

V letu 2019 smo anketo posredovali na 43 elektronskih naslovov. Prejeli smo 25 v celoti izpolnjenih vprašalnikov. V letu 2020 smo spletno anketo poslali na 70 elektronskih naslovov. Anketa je bila aktivna od 15. do 23. 10. 2020. V tem času smo anketirancem posredovali tri opomnike. Največjo aktivnost reševanja ankete smo zabeležili po drugem opomniku, torej 21. 10. 2020. Pri nagovoru smo zabeležili 67 klikov, pri anketi pa 55 klikov. Anketo je začelo izpolnjevati 48 anketirancev, delno jo je izpolnilo 43, v celoti pa 40 anketirancev. Odzivnost na anketo je bila skoraj 60-odstotna (prvo leto 58-odsotna, drugo leto pa 57-odstotna).

Ker gre za študijo primera, ki zajema manjši vzorec, so predstavljena anketa in njeni rezultati uvod v morebitno obsežnejšo raziskavo vpliva strokovnih dogodkov na strokovno samozavest.

\section{Rezultati in razprava: kako močno gorimo in kako ohranjamo plamen}

Rezultate predstavljamo $v$ štirih podpoglavjih: vpliv strokovnega dogodka na krepitev ali vzpostavitev strokovne samozavesti, vpliv strokovnih vsebin na moč strokovne samozavesti, pomen samoiniciativnosti pri gradnji strokovne samozavesti in nova realnost okolja strokovnih dogodkov. Ključno izhodišče za oblikovanje spletne ankete je bila analiza javno dostopnih dokumentov in že objavljenih raziskav, zato so te vključene $v$ predstavitev in razpravo rezultatov. 


\subsection{Skrb za plamen ali smisel strokovne samozavesti}

Udeleženci so se popolnoma strinjali, da jim je udeležba na strokovnem dogodku pomagala bolje razumeti njihovo poklicno vlogo in prispevek pri uresničevanju vloge knjižnice (takšno je bilo vprašanje v letu 2019) pri spodbujanju bralne pismenosti (tabela 1). Podobno velja tudi za njihovo osebno vlogo. V letu 2020 je bilo vprašanje oblikovano brez povezanosti z uresničevanjem vloge knjižnice, poudarek je bil na poklicni in osebni vlogi pri spodbujanju bralne pismenosti. Kot je razvidno iz tabele 1 , je ta ugotovitev enako prisotna $v$ obeh letih.

Tabela 1: Vpliv strokovnega dogodka na osebne in strokovne kompetence

\begin{tabular}{lcc}
\hline Mnenje o pozitivnem vplivu dogodka na razumevanje & ne & da \\
\hline $\mathbf{2 0 1 9}$ & & \\
\hline $\begin{array}{l}\text { poklicne vloge in prispevka pri uresničevanju vloge knjižnice pri spodbujanju bralne } \\
\text { pismenosti }\end{array}$ & $0 \%$ & $100 \%$ \\
\hline $\begin{array}{l}\text { osebne vloge in prispevka pri uresničevanju vloge knjižnice pri spodbujanju bralne } \\
\text { pismenosti }\end{array}$ & $4 \%$ & $96 \%$ \\
\hline $\mathbf{2 0 2 0}$ & $0 \%$ & $100 \%$ \\
\hline poklicne vloge in prispevka pri spodbujanju bralne pismenosti & $0 \%$ & $100 \%$ \\
\hline Osebne vloge in prispevka pri spodbujanju bralne pismenosti & & \\
\hline
\end{tabular}

Po izvedbi dogodka v letu 2020 smo preverili odnos udeležencev do sodelovanja in povezovanja na področju spodbujanja bralne pismenosti in bralne kulture. Veliki večini udeležencev je udeležba na izbranem strokovnem dogodku pomagala razumeti nujnost sodelovanja različnih akterjev na tem področju. Na strokovnem dogodku so pridobili informacije, zaradi katerih se počutijo bolj povezani z drugimi pri prizadevanjih za krepitev bralne kulture in za spodbujanje bralne pismenosti. Drugo vprašanje smo postavili v kontekst sodobnih raziskav na področju nevroznanosti (tukaj nas je zanimalo povečano prepričanje udeležencev, da gre pri branju za bolj kompleksno področje, kot so si predstavljali) in s tem povezano nujnost sodelovanja in povezovanja za dvig kompetentnosti strokovnih sodelavcev. Velika večina respondentov je potrdila, da so na dogodku pridobili informacije, zaradi katerih so vedno bolj prepričani, da gre pri branju za izredno kompleksno področje, bolj kompleksno, kot so si predstavljali (tabela 2).

Tabela 2: Odnos do sodelovanja in povezanosti

\begin{tabular}{lll}
\hline Na strokovnem dogodku leta 2020 ste pridobili informacije & ne & da \\
\hline zaradi katerih se pri vaših prizadevanjih počutite bolj povezani z drugimi & $7 \%$ & $82 \%$ \\
\hline zaradi katerih ste vedno bolj prepričani, da gre pri branju za izredno kompleksno & $3 \%$ & $92 \%$ \\
področje, bolj kompleksno, kot ste si predstavljali & & \\
\hline $\begin{array}{l}\text { zaradi katerih bolj podpirate nujnost sodelovanja različnih akterjev na področju } \\
\text { spodbujanja bralne pismenosti }\end{array}$ & $3 \%$ & $97 \%$ \\
\hline
\end{tabular}

Splošne knjižnice (Vilar, 2017, str. 53) govorijo o manjšem deležu strokovnih delavcev, ki niso usposobljeni za spodbujanje bralne pismenosti, načrten razvoj bralne pismenosti, spodbujanje bralne kulture in načrten razvoj bralne kulture. Po mnenju splošnih knjižnic je med strokovnimi delavci največ takšnih, ki so delno ali popolnoma usposobljeni za spodbujanje bralne kulture. 
Tudi zato smo v vprašalnik vključili naslednje vprašanje, ki povezuje vpliv udeležbe na strokovnem dogodku na dvig strokovne samozavesti udeležencev. Pri tem smo se naslonili na razumevanje samozavesti, ki je povezana s samopodobo in samospoštovanjem. To velja tudi za strokovno samozavest. Ob tem različni avtorji opozarjajo, da so ločnice med temi tremi pojmi izredno težko določljive in tako z vplivom na eno od teh treh vplivamo na vse tri. Samopodoba je naša podoba lastnih misli, čustev, predstav, vrednot, občutkov, misli. Samospoštovanje je naše spoštovanje lastnih norm, vrednot, znanja in sposobnosti. Samozavest je naše zaupanje $v$ lastne misli, občutke, sposobnosti, zmožnosti. Strokovno samozavest opredeljujemo kot zaupanje v naše lastne misli, občutke, sposobnosti, zmožnosti, ki so vezane na naše strokovno delo. Samozavest, samopodoba in samospoštovanje so zelo pomembni elementi splošnih kompetenc, saj so bistveni za kakovostno opravljanje različnih poklicev. Bralne pismenosti ne spodbuja le en poklic, zato lahko v zvezi s spodbujanjem bralne pismenosti govorimo o poklicanosti ali poslanstvu. Poklicanost je najpogosteje vezana na osebno prepričanje o pomembnosti nečesa. Eden od načinov, kako biti bolj strokovno samozavesten, je redno vseživljenjsko učenje, izpopolnjevanje in usposabljanje.

Lastno dojemanje razlike $v$ vedenju posameznika po udeležbi na obravnavanem strokovnem dogodku prikazuje tabela 3. Udeleženci so ocenili, da so na strokovnem dogodku pridobili informacije, zaradi katerih se počutijo bolj kompetentni za promocijo branja. Tako so bolje usposobljeni za spodbujanje bralne kulture. V letu 2019 je bil delež takšnih 88-odstoten, v letu 2020 pa 90-odstoten, torej lahko zaznavamo trend naraščanja. Večina udeležencev se zaradi pridobljenih informacij na strokovnem dogodku počuti bolj samozavestnih pri delu, ki ga opravljajo. Tudi tukaj zaznamo pozitiven trend. Pri respondentih dogodka v letu 2019 je bil delež 88-odstoten, leta 2020 pa 92-odstoten. Iz tega sklepamo, da je udeležba na strokovnem dogodku pozitivno vplivala na posameznikovo strokovno samozavest in kompetentnost. Pri tem nismo preverjali izhodiščnih stopenj samozavesti strokovnih delavcev. Izmerili bi jih lahko, če bi bili prepričani, da se bodo udeleženci udeležili dogodka. Ker je pri udeležbi na takšnih dogodkih pogosto prisotna odpoved udeležbe tik pred dogodkom ali zamenjava udeleženca iz iste ustanove, se za merjenje izhodiščne stopnje samozavesti nismo odločili.

Tabela 3: Vpliv strokovnega dogodka na dvig strokovne samozavesti

\begin{tabular}{lll}
\hline Na strokovnem dogodku ste pridobili informacije & ne & da \\
\hline $\mathbf{2 0 1 9}$ & & \\
\hline zaradi katerih se počutite bolj kompetentni za promocijo branja & $12 \%$ & $88 \%$ \\
\hline zaradi katerih se počutite bolj samozavestni pri delu, ki ga opravljate & $12 \%$ & $88 \%$ \\
\hline $\mathbf{2 0 2 0}$ & $10 \%$ & $90 \%$ \\
\hline zaradi katerih se počutite bolj kompetentni za promocijo branja & $\mathbf{8 \%}$ & $92 \%$ \\
\hline zaradi katerih se počutite bolj samozavestni pri delu, ki ga opravljate & & \\
\hline
\end{tabular}

\subsection{Močna polja strokovne samozavesti - ali tam, kjer sam gorim, lahko $v$ drugih ogenj zanetim in razplamtim}

Pregled ponudbe strokovnih izpopolnjevanj, usposabljanj ali izobraževanj z obravnavanega področja je pokazal raznolikost in dostopnost tovrstnih vsebin. Med udeleženci obravnavanega strokovnega dogodka smo želeli ugotoviti poznavanje določenih vsebin. Vsebine $v$ anketi smo obravnavali glede na njihov vpliv. Vsebine, ki so bile $v$ obeh letih 
prepoznane kot največja novost, kažejo na potrebno in več kot nujno povezavo različnih akterjev na polju spodbujanja bralne pismenosti in bralne kulture (tabela 4).

Vprašanje, ki smo ga za ta namen oblikovali, vključuje trditve, ki so jih na obeh dogodkih predstavili predavatelji in predavateljice; te trditve so vezane na vire, ki so jih navajali v svojih predavanjih ter jih pri analizi dodatno ne pojasnjujemo. Predavanja iz leta 2020 so v celoti posneta in dostopna, iz leta 2019 pa so na spletni strani Mariborske knjižnice dostopna gradiva, ki so jih za objavo namenile predavateljice.

Rezultati ankete iz leta 2019 kažejo, da je dogodek $A B C$ bralne pismenosti, organiziran leta 2019, po oceni udeležencev ponudil največ novih vsebin, vezanih na bralno pismenost odraslih, projekt $\mathrm{OBJEM}^{7}$ in proces branja. Pri dogodku $A B C$ bralne pismenosti II, organiziranem leta 2020, pa so izpostavili predvsem vsebine, vezane na bralne navade mladih in ponovno tudi na proces branja (tabela 4).

$\checkmark$ anketi nismo zbirali demografskih podatkov in tudi ne podatka o delovnem mestu udeleženca ali delovnem področju. Analiza prijav udeležencev nam je pokazala, da je bil prvo leto večinski delež udeležencev iz splošnih knjižnic, teh je bilo kar 75 odstotkov, manjši del pa iz vzgojno-izobraževalnih ustanov. Podobna struktura udeležencev se je izrisala tudi v letu 2020, le da je bil delež udeležencev iz vzgojno-izobraževalnih ustanov višji kot leto pred tem. V letu 2020 je bilo 35 odstotkov udeležencev iz vzgojno-izobraževalnih ustanov, leto pred tem pa le 15 odstotkov. Na osnovi teh podatkov lahko podamo dodatno razlago poznavanja posameznih vsebin.

Tabela 4: Večji vpliv izbranih vsebin na boljše poznavanje področja glede na predhodno poznavanje

\begin{tabular}{|c|c|c|}
\hline Poznavanje vsebin pred udeležbo na dogodku $A B C$ bralne pismenosti & ne & da \\
\hline \multicolumn{3}{|l|}{2019} \\
\hline $\begin{array}{l}\text { V raziskavi bralnih veščin odraslih prebivalcev ugotavljajo tako branje na delovnem } \\
\text { mestu kot tudi branje } v \text { vsakdanjem življenju. }\end{array}$ & $79 \%$ & $21 \%$ \\
\hline Vsi podatki raziskav bralne pismenosti so dostopni na spletni strani pirls.bc.edu. & $71 \%$ & $29 \%$ \\
\hline $\begin{array}{l}\text { Vosnovnih šolah in vrtcih je potekal projekt Opolnomočenje učencev z izboljšanjem } \\
\text { bralne pismenosti in dostopa do znanja. }\end{array}$ & $68 \%$ & $32 \%$ \\
\hline $\begin{array}{l}\text { Približno eden od štirih odraslih v Sloveniji ima zelo slabe spretnosti za obdelavo } \\
\text { in procesiranje informacij. }\end{array}$ & $60 \%$ & $40 \%$ \\
\hline $\begin{array}{l}\text { Kakovostna literarna besedila za otroke vključujejo za } 1 / 3 \text { bolj raznolik besednjak } \\
\text { kot spontani govor odraslih z razvitim jezikovnim kodom. }\end{array}$ & $56 \%$ & $44 \%$ \\
\hline $\begin{array}{l}\text { Kakovostna literarna besedila za otroke vključujejo za } 50 \% \text { več besed kot } \\
\text { televizijske oddaje. }\end{array}$ & $56 \%$ & $44 \%$ \\
\hline $\begin{array}{l}\text { Za dobro razumevanje besedila mora bralec razumeti od } 90 \text { do } 95 \text { odstotkov } \\
\text { besed. }\end{array}$ & $52 \%$ & $48 \%$ \\
\hline
\end{tabular}

\footnotetext{
${ }^{7}$ Projekt poteka v sklopu razpisa pod naslovom Razvoj in udejanjanje inovativnih učnih okolij in prožnih oblik učenja za dvig splošnih kompetenc v sklopu 1: Sporazumevalna zmožnost: bralna in kulturna pismenost ter večjezičnost, točneje sklop 1.1. Bralna pismenost in razvoj slovenščine. Oblikovan akronim projekta je OBJEM (Ozaveščanje, Branje, Jezik, Evalvacija, Modeli). V projektu sodelujejo: Zavod RS za šolstvo - vodenje projekta; sodelujoči konzorcijski partnerji (vzgojno-izobraževalni zavodi): 14 vrtcev, 23 osnovnih šol, 22 srednjih šol; Univerza v Ljubljani: Filozofska fakulteta, Pedagoška fakulteta, Fakulteta za računalništvo; Univerza v Mariboru: Pedagoška fakulteta; Pedagoški inštitut (https://www.zrss.si/projekti/projekt-objem/ z dne 23. 8.2021).
} 


\begin{tabular}{llll}
\hline Poznavanje vsebin pred udeležbo na dogodku ABC bralne pismenosti & ne & da \\
\hline $\mathbf{2 0 2 0}$ & & \\
\hline Med 25,5 odstotki navdušenih mladih bralcev je večina fantov. & $98 \%$ & $2 \%$ \\
\hline $\begin{array}{l}\text { V letu } 2018 \text { je več mladih, ki so izrazili, da je branje eden izmed njihovih najljubših } \\
\text { konjičkov, kot jih je bilo leta 2009. }\end{array}$ & $93 \%$ & $7 \%$ \\
\hline Mladi v letu 2018 raje berejo leposlovje kot v letu 2009. & $90 \%$ & $10 \%$ \\
\hline Po polovici sekunde se zavemo, kaj smo prebrali. & $88 \%$ & $12 \%$ \\
\hline Mladi imajo zelo dobro samopodobo na področju branja. & $74 \%$ & $26 \%$ \\
\hline Obstajajo opisniki temeljnih zmožnosti za osem področij. & $72 \%$ & $28 \%$ \\
\hline $\begin{array}{l}\text { Televizija Slovenija predvaja oddajo Prebrane celice, v kateri predstavljajo knjige iz } \\
\text { seznama zlatih hrušk. }\end{array}$ & $62 \%$ & $38 \%$ \\
\hline
\end{tabular}

Tako npr. pri predstavitvi vsebin iz projekta OBJEM v letu 2020 beležimo višjo stopnjo poznavanja teh vsebin kot v letu 2019. To lahko navežemo na dve predpostavki, ki ju sicer ne moremo preveriti, ker bi to lahko naredili le tako, da bi poslali dodatno anketo vsem tistim udeležencem, ki so se udeležili dogodka v obeh letih. Zaradi varovanja osebnih podatkov pa leto po dogodku ne razpolagamo več s kontaktnimi podatki udeležencev dogodka in tako ne moremo potrditi naše predpostavke.

Prva predpostavka je ta, da je bila informacija o tem projektu podana leto prej. Slednjo lahko navežemo tudi na poznavanje vsebin o bralni pismenosti odraslih. V letu 2019 namreč opazen delež anketirancev pred udeležbo na strokovnem dogodku ni vedel, da $v$ raziskavi bralnih veščin odraslih prebivalcev ugotavljajo tako branje na delovnem mestu kot tudi branje $v$ vsakdanjem življenju ter da ima približno eden od štirih odraslih $v$ Sloveniji zelo slabe spretnosti za obdelavo informacij. Naslednje leto je bilo poznavanje tega vsebinskega segmenta med udeleženci že precej višje, kar je razvidno iz tabele 5 (gl. trditev o težavah odraslih v vsakdanjem življenju zaradi doseganja prenizke ravni pismenosti).

Druga predpostavka, ki je tudi vezana na vzorec udeležencev, je ta, da je bil med udeleženci dogodka leta 2020 večji delež tistih iz vzgojno-izobraževalnih ustanov. Pri predhodnem poznavanju določenih vsebin je struktura udeležencev pomembna spremenljivka. To nakazuje tudi ugotovitev o poznavanju dokumenta Strokovna priporočila in standardi za splošne knjižnice. Na strokovnem dogodku leta 2019 so le štirje odstotki anketirancev prvič slišali, da je bralna pismenost pomemben vsebinski del Strokovnih priporočil in standardov za splošne knjižnice. To lahko vodi do ugotovitve, da je bilo med udeleženci dogodka 96 odstotkov strokovnih delavcev iz splošnih knjižnic, iz analize prijav pa je razviden 75-odstoten delež udeležencev iz splošnih knjižnic. Iz tega sklepamo, da so tudi udeleženci, ki niso primarno vezani na okolje splošne knjižnice, seznanjeni z vsebino omenjenega dokumenta in njegovo povezavo z bralno pismenostjo.

Iz tabele 4 je razvidno, da so v letu 2020 izstopale vsebine, pri katerih je več kot 90 odstotkov anketirancev izrazilo nepoznavanje pred udeležbo na dogodku:

- Med 25,5 odstotki navdušenih mladih bralcev je večina fantov.

- V letu 2018 je več mladih, ki so izrazili, da je branje eden izmed njihovih najljubših konjičkov, kot v letu 2009. 
- Mladi v letu 2018 raje berejo leposlovje kot v letu $2009^{8}$.

Za posamezne vsebine, predstavljene na dogodku $A B C$ bralne pismenosti leta 2019, smo predvidevali, da jih strokovni delavci, ki delujejo blizu področja spodbujanja bralne pismenosti in bralne kulture ali neposredno na tem področju, zelo dobro poznajo. Zelo visok delež (več kot 80 odstotkov) poznavanja vsebine pred udeležbo na strokovnem dogodku smo pričakovali pri naslednjih vsebinah:

- Kakovostna literarna besedila za otroke vključujejo za 50 \% več besed kot televizijske oddaje.

- Kakovostna literarna besedila za otroke vključujejo za 1/3 bolj raznolik besednjak kot spontani govor odraslih z razvitim jezikovnim kodom.

- Za dobro razumevanje besedila mora bralec razumeti od 90 do $95 \%$ besed.

- Po polovici sekunde se zavemo, kaj smo prebrali.

Glede na odziv so bila ta dejstva več kot 50 odstotkom udeležencev pred udeležbo na dogodku neznana, kar je prav tako razvidno iz tabele 4. Slednje potrjuje usmeritev, da so na strokovni dogodek $A B C$ bralne pismenosti umeščene vsebine, ki so vezane na proces branja in so $v$ zadnjem desetletju tudi v večji meri podprte ali na novo odkrite na osnovi nevroznanosti.

Kot smo že omenili, so nekatere splošne knjižnice mnenja, da strokovni delavci niso povsem usposobljeni za spodbujanje oziroma načrten razvoj bralne kulture (Vilar, 2017, str. 53). Ta delež knjižnic je glede na statističen vzorec res majhen, a po našem mnenju prevelik glede na pomembnost področja, ki ga predstavlja strokovna usposobljenost knjižničnih delavcev. V nasprotno nas lahko prepriča odziv udeležencev pri vprašanju o navajanju poznanih vsebin pred udeležbo na dogodku (tabela 5). Izredno visok delež anketirancev je pred udeležbo na dogodku vedel, da težka/težja besedila spodbujajo razmišljanje, da se način branja spreminja z medijem branja in da branje daljših besedil krepi fokus. Posameznik pa tako trenira sposobnost osredotočenosti. Ocenjujemo, da gre v primeru teh vsebin za podrobnosti znotraj poznavanja bralne pismenosti in bralne kulture, ki so bile posebej izpostavljene $v$ zadnjem desetletju ob razmahu nevroznanosti. Zato predvidevamo, da je tudi med strokovnimi delavci v splošnih knjižnicah visok delež posameznikov z visoko stopnjo usposobljenosti za spodbujanje in načrten razvoj bralne kulture.

Tabela 5: Manjši vpliv izbranih vsebin na boljše poznavanje področja glede na predhodno poznavanje

\begin{tabular}{lcc}
\hline Poznavanje vsebin pred udeležbo na dogodku ABC bralne pismenosti & ne & da \\
\hline $\mathbf{2 0 1 9}$ & & \\
\hline Tudi srednje glasbene šole imajo knjižnice. & $4 \%$ & $96 \%$ \\
\hline $\begin{array}{l}\text { Bralna pismenost je pomemben vsebinski del Strokovnih priporočil in standardov za } \\
\text { splošne knjižnice. }\end{array}$ & $4 \%$ & $96 \%$ \\
\hline Letos bo potekal Nacionalni mesec skupnega branja. & $8 \%$ & $92 \%$ \\
\hline Klasične bralne veščine so osnova za branje v digitalnem svetu. & $8 \%$ & $92 \%$ \\
\hline $\begin{array}{l}\text { Pri skupnem branju odraslih in otrok je pomembno troje: starost, pri kateri odrasla } \\
\text { oseba začne brati otroku, pogostost skupnega branja in kakovost skupnega branja. }\end{array}$ & $92 \%$ \\
\hline
\end{tabular}

\footnotetext{
${ }^{8}$ Zanimivo je, da vse te tri ugotovitve, ki so bile predstavljene $v$ programu, podirajo splošna javna prepričanja, da mladi ne berejo radi in da so posebej fantje nebralci.
} 


\begin{tabular}{lll}
\hline Poznavanje vsebin pred udeležbo na dogodku ABC bralne pismenosti & ne & da \\
\hline Število knjig doma je povezano z bralnimi dosežki. & $20 \%$ & $80 \%$ \\
\hline Obstaja visoka povezanost med hitrostjo branja in razumevanjem prebranega. & $24 \%$ & $76 \%$ \\
\hline $\begin{array}{l}\text { Razvit je teoretični model proaktivne splošne knjižnice za bralno pismenost in bralno } \\
\text { kulturo. }\end{array}$ & $32 \%$ & $68 \%$ \\
\hline Slovenija še nima sprejete nacionalne strategije za bralno pismenost. & $40 \%$ & $60 \%$ \\
\hline $\mathbf{2 0 2 0}$ & $3 \%$ & $97 \%$ \\
\hline Način branja se spreminja z medijem branja. & $3 \%$ & $97 \%$ \\
\hline Tudi letos je potekal Nacionalni mesec skupnega branja. & $7 \%$ & $93 \%$ \\
\hline Težka/težja besedila spodbujajo razmišljanje. & $13 \%$ & $87 \%$ \\
\hline $\begin{array}{l}\text { Pionirska - Center za mladinsko književnost in knjižničarstvo že celo desetletje } \\
\text { podeljuje zlate hruške. }\end{array}$ & $15 \%$ & $85 \%$ \\
\hline \begin{tabular}{l} 
V Sloveniji imamo sprejeto Nacionalno strategijo za razvoj bralne pismenosti. \\
\hline Branje daljših besedil trenira posameznikov fokus.
\end{tabular} & $18 \%$ & $82 \%$ \\
\hline $\begin{array}{l}\text { Odrasli imamo velike težave pri vsakdanjem življenju zaradi doseganja prenizke ravni } \\
\text { pismenosti (npr. pri iskanju službe). }\end{array}$ & $23 \%$ & $77 \%$ \\
\hline $\begin{array}{l}\text { Objem je tudi poseben program, ne le fizično dejanje posameznika, ki v trenutni } \\
\text { situaciji ni zaželena oblika ravnanja. }\end{array}$ & $38 \%$ & $62 \%$ \\
\hline Obstajajo smernice za spodbujanje branja med mladimi športniki in športnicami. & $49 \%$ & $51 \%$ \\
\hline
\end{tabular}

Poznavanje določenih vsebin pred predstavitvijo na strokovnem dogodku omogoča tudi vpogled $v$ trdno zasidrana vsebinska področja. Med takšne primere spadajo nacionalna kampanja za bralno kulturo (Nacionalni mesec skupnega branja), poznavanje nacionalne strategije za razvoj bralne pismenosti in priznanja zlata hruška.

Prikazani podatki v tabelah 4 in 5 nas vodijo do sklepa, da je bil program izbranega strokovnega dogodka $v$ obeh letih zasnovan izredno povezovalno. Različne vsebine različnih akterjev je prinesel do različnih posameznikov, ki delujejo na področju spodbujanja bralne pismenosti in bralne kulture.

\subsection{Pomen samoiniciativnosti - kako sam pri sebi ali v drugih zanetiš in razplamtiš ogenj}

Samopodoba, samospoštovanje in samozavest so (po)vezani s samoiniciativnostjo. Knjižničarji in knjižničarke navajajo, da je prav samoiniciativnost izredno pomembna za spodbujanje bralne pismenosti in bralne kulture. (Vilar, 2017, str. 52)

Tabela 6 prikazuje vsebinska področja, za katera smo želeli izvedeti, ali so o njih posamezniki že kdaj samoiniciativno razmišljali pred udeležbo na dogodku. Ta področja so naslednja: kaj je branje in čemu brati, ravnanje s tistimi, ki ne marajo brati, vloga možganov pri branju, branje kot del športnega treninga, priznanje zlata hruška kot vseslovenska nagrada, nenavdušenost odraslih za branje, vpliv nevroznanosti na razumevanje procesa branja. Časovnega okvira nismo opredelili, prepustili smo ga subjektivnemu vrednotenju anketirancev.

Rezultati kažejo, da so vsi anketiranci že razmišljali o tem, kaj je branje in čemu brati. Zelo velik delež (92 \%) anketirancev je svoje misli že kdaj pred udeležbo na strokovnem dogodku namenil tistim, ki ne marajo brati $^{9}$. Veliko anketirancev se je že pred dogodkom kdaj vprašalo, kakšno

\footnotetext{
${ }^{9}$ Na pomen ukvarjanja z nebralci opozorijo tudi knjižničarji (Vilar, 2017, str. 55): »Knjižničarji se zavedajo, da ni dovolj, da knjižnica skrbi le za ljudi, ki v knjižnico zahajajo, poseči bi morala tudi izven svojih zidov, kar pa je zelo zahtevno. Navajamo izjavo: 'Skupine nebralcev so pa težko dosegljive in na tem je potrebno ves čas delati.'«
} 
vlogo imajo možgani pri branju. Precej manjši je delež (46 \%) tistih, ki so se kdaj vprašali o vplivu izsledkov nevroznanosti na razumevanje procesa branja. Zanimiv je visok odstotek tistih, ki so razmišljali o priznanju zlata hruška ${ }^{10}$ kot o vseslovenski nagradi. Najmanjši delež anketirancev (37 \%) je proces branja povezal s treningi športa.

Tabela 6: Prikaz tem, o katerih so udeleženci že razmišljali ali o katerih še niso razmišljali

\begin{tabular}{lcc}
\hline Mnenje o vplivu strokovnega dogodka na razmišljanje o izbranih vsebinah & ne & da \\
\hline $\mathbf{2 0 1 9}$ & & \\
\hline kaj je branje in čemu brati & $0 \%$ & $100 \%$ \\
\hline ravnanje s tistimi, ki ne marajo brati & $8 \%$ & $92 \%$ \\
\hline $\mathbf{2 0 2 0}$ & & \\
\hline vloga možganov pri branju & $16 \%$ & $84 \%$ \\
\hline branje kot del športnega treninga & $63 \%$ & $37 \%$ \\
\hline priznanje zlata hruška - vseslovenska nagrada & $26 \%$ & $74 \%$ \\
\hline $\begin{array}{l}\text { problem spodbujanja branja pri mladih - nenavdušenost posameznikov, ki mlade } \\
\text { spremljajo }\end{array}$ & $53 \%$ & $47 \%$ \\
\hline vpliv nevroznanosti na razumevanje procesa branja & $54 \%$ & $46 \%$ \\
\hline
\end{tabular}

Izpostavljene ugotovitve nas vodijo do posameznikovega odnosa do branja in poznavanja bralne pismenosti. Knjižničarji (Vilar, 2017, str. 63) menijo, da ima knjižnica nedvomno velik vpliv na bralno pismenost in bralno kulturo, kar je odvisno od različnih dejavnikov. Eden od njih je odnos odraslih, ki so v družbi nosilci vzgleda mladim; za odnos odraslih »knjižničarji menijo, da ni najboljši, saj knjižnico prepogosto dojemajo kot samoumevno oziroma le kot vir obveznega čtiva." Odrasli s(m)o tudi tisti, ki jih (nas) nacionalna strategija za razvoj bralne pismenosti definira kot odgovorne za razvoj bralne pismenosti (Nacionalna, 2019, str. 6).

Knjižničarji in knjižničarke (npr. Vilar, 2017, str. 64; Fras Popović, Bešter in Vovk, 2017) so opozorili na potrebo po nacionalnih kampanjah za spodbujanje branja. $V$ naši raziskavi smo ugotovili, da je Nacionalni mesec skupnega branja, ki je glede na razpoložljive podatke ena najbolj sistemsko povezujočih kampanj, poznan več kot 90 odstotkom anketirancev. Podobno velja tudi za Nacionalno strategijo za razvoj bralne pismenosti, krovni dokument, ki usmerja razvoj bralne pismenosti. $V$ letu 2019 je 60 odstotkov anketirancev vedelo, da še nimamo sprejete nacionalne strategije za razvoj bralne pismenosti, v letu 2020 pa je 85 odstotkov vedelo, da je takšna strategija sprejeta.

Te ugotovitve nas vodijo do razmišljanja, da je samoiniciativnost vezana na uspešnost permanentnega strokovnega usposabljanja posameznika. Ni bistveno le, koliko in kakšna izobraževanja ali strokovna usposabljanja so pripravljena, ključno je, da posamezniki sami poiščejo potrebne informacije in sledijo pomembnim programom. Bistveno pri samoiniciativnosti je, kako tisto, kar na usposabljanjih, izpopolnjevanjih in v strokovni literaturi spoznajo, posamezniki udejanjijo v praksi.

\footnotetext{
${ }^{10}$ Zlata hruška je znak kakovosti mladinskih knjig. Odličnim mladinskim knjigam podelijo priznanja $v$ štirih kategorijah. Priznanja in znak podeljuje Mestna knjižnica Ljubljana.
} 


\subsection{Kako lahko sam gorim in vnamem druge $v$ času epidemije zaslonov}

Strokovni dogodki izobraževalne narave, kamor umeščamo tudi dogodke, ki so namenjeni strokovnemu usposabljanju, izpopolnjevanju in vseživljenjskemu učenju, so pred razglasitvijo epidemije v Sloveniji dne 13. marca 2020 potekali $v$ fizičnem prostoru ob posrednem ali neposrednem stiku predavateljev in udeležencev. Dogodki so bili pogosto plačljivi in z omejenim številom udeležencev, seveda glede na prostorske okoliščine. Nekateri dogodki so bili ob izvedbi $v$ fizičnem prostoru tudi posneti in nato po dogodku ponujeni na ogled, praviloma na spletni strani ali kanalu YouTube organizatorja ${ }^{11}$.

Epidemija je uveljavila drugačne zakonitosti družbenega življenja in je posegla tudi na področje priprave strokovnih dogodkov. Ti so se $v$ času, ko strokovnjaki opozarjajo na precej negativen vpliv zaslonov (npr. Kramli, 2020a, 2020b, 2021; Spitzer; 2021), preselili prav na zaslone in s tem izpostavili pozitivno stran uporabe sodobne tehnologije.

Po pregledu javno dostopnih podatkov o ponudbi strokovnih dogodkov z obravnavanega področja ugotavljamo, da je bil strokovni dogodek $A B C$ bralne pismenosti II, organiziran leta 2020, prvi dogodek takšne narave, ki je potekal v živo prek izbrane aplikacije. Dogodek je bil tudi časovno drugače zasnovan kot leto pred tem. Namesto enega dne je potekal štiri dni, in sicer od 5. do 9. oktobra 2020, predavanja so bila dolga 45 minut, 15 minut pa je bilo na voljo za klepet s predavateljem prek klepetalnice.

Zanimalo nas je, kako so to drugačno izvedbo dojeli udeleženci oziroma kakšen vpliv je imela na njih izvedba na daljavo. Anketiranci so odgovarjali na odprto vprašanje. Podane odgovore smo razdelili $\vee$ dve skupini. $\vee$ prvo skupino (tabela 7) smo umestili odgovore, ki kažejo manj navdušenja in izpostavljajo manj prijetne občutke (tesnobo, nesproščenost, neugodje). Odgovori razkrivajo, da so ti občutki praviloma vezani na splošno stanje družbenega življenja $v$ času epidemije. Skupno jim je to, da izpostavijo večjo naklonjenost srečevanju $v$ živo, problem organizacije (kombinacija opravljanja delovnih nalog in poslušanja predavanj) ter odsotnost interakcije.

Tabela 7: Negativen vpliv online prizorišča

Kakšen občutek ste imeli pri udeležbi na tem strokovnem dogodku prek aplikacije Zoom? Težje mi je bilo vzdrževati koncentracijo ves čas predavanja, kot če bi bilo predavanje $v$ živo. Čuden občutek. Raje bi, da bi se srečali v živo. (V različnih variantah se ponovi štirikrat.) Veliko bolj všeč so mi dogodki v živo. $\checkmark$ redu, ampak vseeno je manj interakcije. Prvič sem se udeležila takšnega izobraževanja. Bilo mi je kar neugodno, saj sem vajena pristnih stikov. Upam, da bo tega kmalu konec in da bomo spet zadihali s polnimi pljuči in se ponovno začeli srečevati na takšnih in drugačnih izobraževanjih.

Sicer sem že večkrat sodeloval na spletnih predavanjih, vendar še zmeraj zagovarjam živ kontakt, realno komunikacijo. Posebej je še problem, ker si pri spletnih predavanjih na delovnem mestu in te zmeraj lahko nekdo zmoti in ne moreš biti tako skoncentriran na predavanje.

Manjka mi samodiscipline in težko je biti v službi in poslušati predavanje.

\footnotetext{
${ }^{11}$ Primer: Mestna knjižnica Ljubljana ali Zveza bibliotekarskih društev Slovenije.
} 
V drugi skupini (tabela 8) smo zbrali odgovore, ki kažejo več navdušenja in izpostavljajo prijetnejše občutke (sproščenost, zbranost, obvladanje, nadzor, udobnost). Skupno jim je bilo sprejemanje okoliščin, iskanje možnosti sodelovanja glede na dane možnosti, težnja po spoznavanju novosti in drugačnosti.

\section{Tabela 8: Pozitiven vpliv online prizorišča}

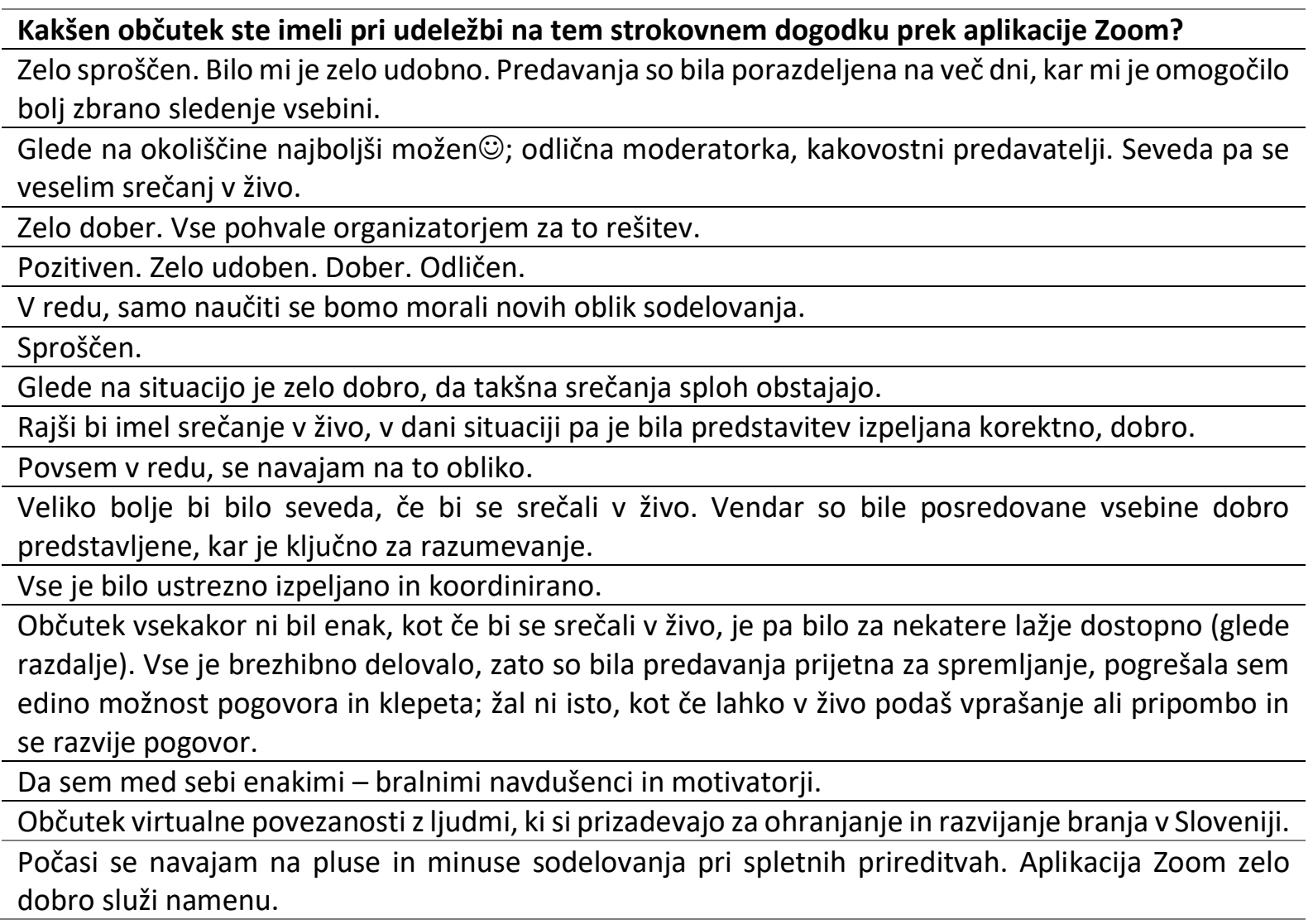

Iz analize tega vprašanja smo iz nadaljnje obdelave izločili dva odgovora, ki bi ju lahko le z dodatno osebno razlago anketiranca uvrstili v prvo ali drugo skupino.

Iz podanih odgovorov na to odprto vprašanje smo ugotovili, da sta za dober občutek pri udeležencih ključna dva elementa, in sicer: povezanost med predavateljem, moderatorjem in udeleženci ter neposredno podajanje vsebine ( $v$ živo). Posnetki so kasneje dobronameren pripomoček za obnovitev in poglobitev znanja, a je neposrednost tista, ki navdihuje in spodbuja pozitivno obarvane občutke. Ti so najpomembnejši za učenje (Carey, 2016). Te ugotovitve o pomembnih elementih pri podajanju strokovnih vsebin na spletu smo lahko potrdili tudi z udeležbo in opazovanjem reakcije udeležencev na drugih strokovnih dogodkih, ki so bili v nadaljevanju šolske sezone 2020/2021 izpeljani na podoben način, torej prek aplikacije Zoom ter z moderatorjem in posredovanjem odzivov $v$ klepetalnici.

\section{Sodelovanje na strokovnih dogodkih - gorim in pri tem ne izgorim}

Petina splošnih knjižnic ocenjuje (Vilar, 2017, str. 53), da nimajo veliko možnosti, da bi imele v veliki večini med strokovnimi delavci takšne, ki so popolnoma usposobljeni za spodbujanje in načrten razvoj bralne pismenosti in bralne kulture. To oceno vežejo na premajhne možnosti 
za izobraževanje in usposabljanje za to področje. Tovrstno izobraževanje bi moralo temeljiti na teoretičnem znanju in biti prilagojeno kontekstu knjižnice, hkrati pa »bi bilo potrebno izboljšati tudi kompetence knjižnic in knjižničarjev za promocijo branja« (str. 56).

Iz naše raziskave je razvidno, da je udeležba na strokovnih izobraževanjih pogoj za pozitivno samopodobo, samozavest in samospoštovanje. V času, ki je zelo zaznamovan s terminom izgorevanje, je redna refleksija, ki jo omogočajo tudi strokovni dogodki, izredno pomembna za duševno zdravje motivatorjev in promotorjev branja, saj tudi knjižničarji ugotavljajo, da je za to vrsto dejavnosti potrebna tudi osebna zavzetost (Vilar, 2017, str. 51).

Iz odgovorov na odprto vprašanje $v$ anketi smo dobili potrditev, da so takšna izobraževanja izredno dobrodošla in potrebna; drznili bi si zapisati, da jih ni nikoli preveč. Prehod iz fizičnega $v$ spletni prostor je $v$ ospredje postavil znanje in vsebino, hkrati pa večjo dostopnost.

Prav dostopnost je tista, ki $v$ največji meri utemeljuje ohranjanje te oblike podajanja strokovnih izpopolnjevanj tudi v prihodnje. Iz odzivov udeležencev smo ugotovili, da je bilo med udeleženci več takšnih, ki se dogodkov zaradi službenih obveznosti ne bi mogli udeležiti, če bi bili ti fizično v drugem kraju. „Upam, da bo podobnih izobraževanj še več, in to ne izključno zaradi epidemije, med drugim tudi zato, ker se je na takšen način izobraževanja lahko udeležilo veliko več knjižničarjev, kot bi to bilo možno, če bi na predavanja morali v Maribor ali kam drugam. "Prav tako so v praksi ob eni spletni prijavi dogodek spremljali v celotnem kolektivu. To prakso smo lahko nato zasledili tudi pri Festivalu bralne značke, ki je potekal v maju 2021, ko so se na posamezno srečanje s pisateljem prijavljali kar celi razredi.

Odgovori anketirancev so pokazali, da tudi srečevanje v takšni obliki razumemo kot druženje. Prinesli so tudi določene vsebinske poudarke, ki jih v preteklosti nismo bili vajeni, npr. pohvale med predavanjem ali neposredno takoj po predavanju $v$ klepetalnici aplikacije Zoom, poudarek na vztrajnosti in pogumu pri prvi izvedbi, zahvala, da je bil dogodek sploh izpeljan. Ob tem smo spoznali, da se je v letu epidemije, ko so se tovrstni dogodki prenesli na splet, spremenila tudi kultura dialoga. $V$ klepetalnici in anketi je bilo več pozitivnih misli kot kadarkoli prej in precej manj negativnih.

Strokovni dogodek ABC bralne pismenosti Il je bil v šolskem letu 2020/2021 in v letu razglašene epidemije $v$ sklopu dogodkov, ki jih pripravljajo knjižnice in drugi deležniki ter jih lahko umestimo v vsebinski sklop strokovnega usposabljanja za področje bralne pismenosti in bralne kulture $^{12}$, prvi $v$ živo, izpeljan neposredno prek aplikacije Zoom. Kar smo zaznali takoj po izvedbi našega dogodka in pridobili tudi na osnovi rezultatov spletne ankete, so potrdili tudi drugi dogodki, ki so mu sledili. Pri spletnih dogodkih so se izkazali prednost večje dostopnosti, pomen in vloga moderatorja, tako v klepetalnici kot pred zaslonom, pomen ustrezno časovno zastavljenega koncepta in odmik od koncepta, ki ga je prinašal ustaljeni ${ }^{13}$ model priprave dogodka v fizičnem okolju.

\footnotetext{
12 »Dan dobrih praks 2020 - Knjižničar knjižničarju Vl« (ZBDS, Sekcija za splošne knjižnice in Mestna knjižnica Kranj, 20. 10. 2020); "So knjižnice dostopne?« (DBL, 19. 11. 2020); Simpozij 60 let branja pod površjem (BZS; 24.-27. 11. 2020);

${ }^{13}$ Namesto šestih predavanj po 15 minut v enem dnevu je za udeležence npr. bolj sprejemljivo predavanje ali dve predavanji na dan v dolžini ene ure.
} 


\section{Zaključek ali kako zelo drži misel »Če hočeš druge vneti, moraš sam goreti»}

Skozi članek nas je vodila misel „Če hočeš druge vneti, moraš sam goreti«, pod katero je podpisan Anton Martin Slomšek, ki je znan tudi po svoji ljubezni do slovenskega jezika in skŕbi za bralno opolnomočenje mladih. Raziskava o ugotavljanju vpliva strokovnega dogodka $A B C$ bralne pismenosti v letih 2019 in 2020 je potrdila tezo, da udeležba na strokovnih dogodkih pozitivno vpliva na strokovno samozavest, na razumevanje osebne vloge posameznika in njegov prispevek pri spodbujanju bralne pismenosti ter tako oblikuje posameznikov odnos do branja in knjige, torej njegovo bralno kulturo. Samopodoba se razvija in spreminja vse od rojstva do mladostništva, a tudi $v$ obdobju odraslosti ne ostaja statična in nespremenljiva. Pomembno vlogo $v$ razvoju samopodobe imajo povezave $z$ drugimi in te se vzpostavijo tudi $v$ sklopu rednih strokovnih usposabljanj, izobraževanj in izpopolnjevanj.

Anketiranci so se popolnoma strinjali, da je udeležba na strokovnem dogodku $A B C$ bralne pismenosti I/ v letu 2020 pozitivno vplivala na njihovo razumevanje lastne poklicne in osebne vloge ter njihovega prispevka pri spodbujanju bralne pismenosti. Samopodoba temelji tudi na naših osebnih prepričanjih in vrednotah, zato je za razvoj strokovne samozavesti zelo pomembno, da posameznik verjame, da mu udeležba na izbranem strokovnem dogodku pomaga izboljšati se pri svojem delu.

Na osnovi rezultatov ankete tako v letu 2019 kot v letu 2020 ugotavljamo, da Center za spodbujanje bralne pismenosti z izbrano metodo dela (organizacijo strokovnega dogodka) dosega glavni namen, in sicer ustvarjanje pozitivnega družbenega okolja za spodbujanje bralne pismenosti in krepitev strokovnih kompetenc splošnih knjižničarjev. Iz študije primera smo ugotovili tudi, da se spreminja struktura udeležencev, kar pomeni, da ima dogodek tudi povezovalno vlogo med različnimi deležniki na področju bralne pismenosti.

Udeležba na strokovnem dogodku krepi znanje, zavedanje in povezanost, anketa pa podaja pozitivne povratne informacije o tem, kako posameznik razmišlja in deluje. Anketa je načrtno izpostavila ugotavljanje vpliva, s tem pa je omogočila vrednotenje določene knjižnične storitve, to je ponudbe strokovnega izpopolnjevanja. Za nadaljnje raziskave $z$ večjim dometom (torej večjim številom udeležencev) in vzorcem (posledično sklepamo tudi z večjim številom respondentov) si želimo, da bi v prihodnje tudi drugi organizatorji tovrstnih dogodkov med udeležence posredovali ankete, s katerimi bi ob zadovoljstvu ugotavljali tudi vpliv. Drugačno obliko ankete so pozitivno sprejeli tudi udeleženci: "Všeč mi je vaša anketa, ker so vprašanja malo drugače zastavljena, kot sem navajena. "Prepričani smo, da drugače zastavljena anketa med udeleženci preoblikuje tudi njihov fokus in preusmeri njihovo pozornost na lastno vključenost v proces dela in usposabljanja.

Udeleženci so izpostavili, da so na strokovnem dogodku, ki smo ga postavili v središče naše raziskave, pridobili informacije, zaradi katerih so vedno bolj prepričani, da gre pri branju za izredno kompleksno področje, bolj kompleksno, kot so si predstavljali. Če bi na osnovi te ugotovitve morda podvomili o strokovni usposobljenosti, nas v nasprotno prepriča naslednja ugotovitev. Izredno velik delež anketirancev je pred udeležbo na strokovnem dogodku poznal določene vsebine (npr. vpliv težjih besed na razmišljanje, način branja in medij, povezava branja daljših besedil in fokus posameznika), ki jih uvrščamo med aktualnejše in poglobljene vsebine na področju bralne pismenosti in bralne kulture. S tem ugotavljamo, da je določen 
delež anketirancev izredno visoko usposobljen. Pomembno mesto na tovrstnih dogodkih imajo vsebine, ki so vezane na temeljne raziskave in sodobne ugotovitve o procesu branja.

Vsekakor pa ne moremo biti zadovoljni z ugotovitvijo, da so bile vsebine, za katere smo pričakovali popolno poznavanje pred udeležbo na strokovnem dogodku, poznane le polovici udeležencev strokovnega dogodka. Ugotavljamo tudi, da je samoiniciativnost pomemben del permanentnega izobraževanja. Ni bistveno le, koliko in kakšna izobraževanja, usposabljanja in izpopolnjevanja so del posameznikovega strokovno-razvojnega načrta, temveč je ključno, da je posameznik sam pismen, kar pomeni, da zna poiskati potrebne informacije in slediti razvoju strokovnega področja. Na strokovnih dogodkih je za udeležence pomembno, da dobijo tudi informacije, ki jih prinašajo temeljne znanstvene raziskave. Tako je eden od anketirancev menil: »Pridobili smo veliko novih informacij, ki so ključne za naše delo, pa smo jih le slutili, nismo pa jih imeli potrjenih s podatki.«

Pri občutkih udeležencev ob spremljanju dogodkov na spletu je v primerjavi z zadovoljstvom ob druženju s kolegi in s prireditvenim prostorom bolj $v$ ospredju zadovoljstvo s podanimi vsebinami, hkrati pa tovrstno srečevanje s kolegi še vedno dojemajo kot druženje. Ključna elementa sta neposreden prenos in moderator kot vezni člen med udeleženci in predavatelji. Udeleženci strokovnega dogodka $A B C$ bralne pismenosti I/ so izpostavili tudi "zelo domiselno organizacijo in izvedbo, ki bo v pomoč marsikomu, ki se tega loteva v svoji ustanovi, pa tudi zasebno." Prav ob tem in podobnih mnenjih se pokaže vpliv premišljenega koncepta na nadaljnje prakse. Le-te smo lahko nato spremljali pri dogodkih $v$ nadaljevanju šolskega leta 2020/2021. Tako smo zaznali vpliv koncepta strokovnega dogodka ABC bralne pismenosti II tudi pri drugih podobnih strokovnih dogodkih. Čeprav ugotavljamo vpliv le enega strokovnega dogodka, smo trdno prepričani, da tudi drugi strokovni dogodki pozitivno vplivajo na strokovno samozavest.

Branje je odnos, grajen $v$ enakostraničnem trikotniku. Bralec, strokovno, znanstveno ali literarno delo, skozi katero govori raziskovalec in/ali pisatelj, in posrednik. Slednji je lahko knjižničar, učitelj, pedagog, trener, starš, sovrstnik, moderator strokovnega dogodka. Ključno je, da sam verjame v to, kar zagovarja, in je navdušen nad tem, kar predstavlja. Osnovni temelji etično korektnega marketinga so temelji tudi pri spodbujanju bralne pismenosti in gradnji bralne kulture. In to je zajeto v misli Antona Martina Slomška: "Če hočeš druge vneti, moraš sam goreti«.

V središče članka smo postavili ugotavljanje vpliva strokovnega dogodka, ki ga pripravlja Center za spodbujanje bralne pismenosti Mariborske knjižnice, skozi članek nas je vodila misel Antona Martina Slomška, ki spada med pomembne osebnosti Maribora, in tako je tudi odločitev za objavo članka v reviji, katere založnik in izdajatelj ima sedež v Mariboru, več kot smiselna izbira.

\section{Reference}

ABC bralne pismenosti - strokovno srečanje, 2019. Dostopno na: https://www.mb.sik.si/abcbralne-pismenosti-strokovno-srecanje.html [23. 8. 2021].

ABC bralne pismenosti II - strokovni dogodek, 2020. Dostopno na:

https://www.mb.sik.si/abc-bralne-pismenosti.html [23. 8. 2021]. 
Alter, A., 2019. Sužnji zaslona: kako nas tehnologija zasvoji, industrija pa to izkoristi. Ljubljana: Mladinska knjiga.

Ambrožič, M., 2016. Odnos javnosti do knjižnične javne službe: rezultati raziskave. Ljubljana: Zveza bibliotekarskih društev Slovenije. Dostopno na: http://www.zbdszveza.si/sites/default/files/dokumenti/2013/predstavitev ambrozic2016.pdf [1. 5. 2021].

Carey, B., 2016. Kako se učimo: presenetljiva resnica o tem, kdaj, kje in zakaj se to zgodi. Ljubljana: UMco.

Center za spodbujanje bralne pismenosti, 2021. Dostopno na: https://www.mb.sik.si/centerza-spodbujanje-bralne-pismenosti.html [23. 8. 2021].

Fras Popović, S., 2016. Vodenje s poslanstvom: vodenje zaposlenih v splošnih knjižnicah. Ljubljana: Zveza bibliotekarskih društev Slovenije.

Fras Popović, S., Bešter, T. in Vovk, D., 2017. Povezovanje, sodelovanje, skupnosti. Ljubljana: Zveza bibliotekarskih društev Slovenije. Dostopno na: http://www.dlib.si/?URN=URN:NBN:SI:DOC-OZRHCRHS [23. 8. 2021].

Furedi, F., 2017. Moč branja: od Sokrata do Twitterja. Ljubljana: UMco.

SIST ISO 16439:2015 Informatika in dokumentacija - Metode in postopki za ocenjevanje vpliva knjižnic, 2015. Ljubljana: Slovenski inštitut za standardizacijo.

Nacionalna strategija za razvoj bralne pismenosti za obdobje 2019-2030, 2019. Dostopno na: https://www.gov.si/novice/2020-01-15-nacionalna-strategija-za-razvoj-bralnepismenosti-za-obdobje-2019-2030/ [20. 5. 2021].

Javnomnenjska telefonska raziskava med člani, uporabniki in neuporabniki slovenskih splošnih knjižnic, 2011. Ribnica: Združenje splošnih knjižnic. Dostopno na: https://www.knjiznice.si/wp-content/uploads/2019/07/Interstat-ZDRU\%C5\%BDENJESPLO\%C5\%A0NIH-KNJI\%C5\%BDNIC-poro\%C4\%8Dilo-29092011.pdf [20. 5. 2021].

Kramli, M., 2020a. Zaradi dela na daljavo otroci ne bodo zasvojeni s tehnologijo. Viva, medicina \& ljudje, 323/324, str. 21-25.

Kramli, M., 2020b. Intervju: Miha Kramli, psihoterapevt: Novosodobne igrače, ki vodijo v zasvojenost. Ljubljana: Inštitut za razvoj igrač. Dostopno na: http://institut-igrac.si/sl/novicein-dogodki/299-intervju-miha-kramli-psihoterapevt-novosodobne-igrace-ki-vodijo-vzasvojenost [20.5. 2021].

Kramli, M., 2021. Desetletni zombiji - življenje jih ne zanima. Dostopno na: https://revijazarja.si/clanek/zgodbe/59280a7eb7e01/desetletni-zombiji-zivljenje-jih-nezanima [20. 5. 2021].

Saltz, G., 2019. Moč različnosti: vez med duševno motnjo, nadarjenostjo in genialnostjo. Ljubljana: UMco.

Strokovna priporočila in standardi za splošne knjižnice: (za obdobje 2018-2028), 2019. Ljubljana: Zveza bibliotekarskih društev Slovenije. 
Spitzer, M., 2016. Digitalna demenca: kako spravljamo sebe in svoje otroke ob pamet. Celovec: Mohorjeva.

Spitzer, M., 2021. Epidemija pametnih telefonov: nevarnost za zdravje, izobraževanje in družbo. Celovec: Mohorjeva; Ljubljana: Mladinska knjiga.

Raziskava med člani, uporabniki in neuporabniki slovenskih splošnih knjižnic, 2020. Grosuplje: Združenje splošnih knjižnic. Dostopno na: https://www.knjiznice.si/wpcontent/uploads/2020/06/ZSK javnomnenjska raziskava Ninamedija 2020.pdf [1. 5. 2021]

Vilar, P., 2017. Proaktivna splošna knjižnica za bralno pismenost in bralno kulturo. Ljubljana: Zveza bibliotekarskih društev Slovenije. 